\title{
A Translation Study on Responding of Requesting Speech Act in the Heroes of Olympus Series
}

Dewinta Khoirul Anis

dewinta.remenaweh@gmail.com

Universitas Sebelas Maret, Surakarta, Indonesia

Mangatur Nababan

Universitas Sebelas Maret, Surakarta, Indonesia

amantaradja@gmail.com

Djatmika

Universitas Sebelas Maret, Surakarta, Indonesia

djatmika@uns.ac.id

DOI: 10.18326/rgt.v9i2.696v[]i[].1-15

DOI: http://dx.doi.org/10.18326/rgt.v10i2.200-220

\begin{abstract}
Submission
Track:

ENGLISH ABSTRACT

Received:

This research aims to find the translation techniques and evaluate the

$31 / 10 / 2017$ translation quality in the form of acceptability assessment on

Final Revision:

$23 / 11 / 2017$

Available online:

$.01 / 12 / 2017$ responding of requesting speech act in the novel The Heroes of Olympus Series. This is a qualitative descriptive research. The primary data sources are the novels The Heroes of Olympus Series. Meanwhile, the secondary data sources are derived from minute meeting of two raters who have competencies in assessing translation quality and in evaluating the translation. The methods to collect and analyze the data are content analysis and Focus Group Discussion (FGD). The study found 13 translation techniques applied in translating the responding of requesting speech act. They are Establish equivalent, Variation, Borrowing (Pure borrowing and Naturalized borrowing), Modulation, Amplification (Explicit, Addition, and Paraphrase), Adaptation, Discursive creation, Transposition, Generalization, Reduction, Literal, Substitution, and Linguistic compression. Dealing with the translation quality in the form of acceptability assessment, 77 data (86.51\%) are acceptable translations and 12 data (13.48\%) are less acceptable. The majority of acceptable translations use establishes equivalent technique. The less acceptable translations apply modulation, amplification addition, and discursive creation techniques.
\end{abstract}

Keyword: responding of requesting speech act, translation techniques, translation acceptability

INDONESIAN ABSTRACT

Penelitian ini bertujuan untuk menemukan teknik-teknik 
penerjemahan yang digunakan dan menilai kualitas keberterimaan terjemahan pada respons tindak tutur meminta pada novel The The Heroes of Olympus Series. Penelitian ini adalah penelitian deskriptif kualitatif. Sumber data utamanya adalah novel The Heroes of Olympus Series. Sedangkan, sumber data sekunder adalah catatan diskusi oleh dua orang penilai yang memiliki kompetensi dalam menilai kualitas terjemahan, mengevaluasi terjemahan. Metode untuk mengumpulkan dan menganalisis data adalah simakcatat (content analysis) dan Focus Group Discussion (FGD). Penelitian ini menemukan 13 teknik penerjemahan yaitu Padanan lazim, Variasi, Peminjaman (Peminjaman murni dan Peminjaman alamiah), Modulasi, Amplifikasi (eksplisit, adisi, dan paraphrase), Adaptasi, Kreasi diskursif, Transposisi, Generalisasi, Reduksi, Literal, Peminjaman alamiah, Substitusi, dan Kompresi linguistik. Berkaitan dengan penilaian kualitas keberterimaan terjemahan respons tindak tutur meminta, 77 (86.51\%) data memiliki tingkat keberterimaan tinggi dan 12 (13.48\%) data kurang berterima. Mayoritas terjemahan berterima menggunakan teknik padanan lazim. Terjemahan kurang berterima menggunakan teknik modulasi, amplifikasi adisi dan kreasi diskursif.

Kata kunci: respons tindak tutur meminta, teknik penerjemahan, keberterimaan terjemahan

\section{INTRODUCTION}

In the process of translating, translation includes the transfer of meaning from the source text to the target text. Translation can be a liaison in the process of transferring information between target and source language users. To correlate the relationship between two different cultures and languages, qualified translations are urgently needed, so the transfer and disclosure of messages from the source text to the target one can be well conveyed, for example, in the field of literature, such as novels. For Western literature readers, translations will be helpful when reading it in a familiar text, familiar to the target language audience.

Translating literary works is not easy. Although the translators are able to translate well, they cannot fully assure that they make good interpretation upon the text. For example, translators are often unable to translate difficult terms in the source text, and they cannot find the equivalent meanings in the target text. Whereas the task of a translator is to transfer language and culture of the source text into the target one in order to make the reader understands the message and the meaning of the source text. 
Furthermore, a translator should comprehend the definition of translation. (Brislin, 1976) says that the translation is the general term referring to the transfer of thoughts and ideas from one language (source) to another (target), whether the languages are in written or oral form: whether the language has established orthographies or do not have such standardization; or whether one or both languages are based on sign, e.g. sign language of the deaf. (Larson, 1984) also states that translation is basically to transfer a meaning of the source language into the target language. Moreover, (Catford, 1965) explains that translation is the replacement of textual material in one language (Source Text) by equivalence textual material in another language (Target Text). (Newmark, 1981) also says that translation is a craft consisting of the attempt to replace a written message and/or statement in one language by the same message and/or statement in another language. According to (Catford, 1965) and (Newmark, 1981), translation is the process of replacing meaning from the source language into the target language. From those definitions above, it can be deduced that translation is the activity of transferring thoughts, ideas from the source language into the target language either written or spoken language.

Besides understanding the definitions of translation, a translator that translates a text from the source text to another text in order to look natural and meaningful translation involves many factors, like using translation techniques, context, and understanding of communication aspect. (Keith Davis, 1993) states that communication is a process of passing information and understanding from one person to another. Hence, we concern that communication is a dynamic process that takes place around us all the time. In fact, we spend many times receiving and sending messages. Furthermore, in order to make communication runs effectively, communication must be built on the basis of openness that is the key to trust and credibility. The ability to listen and read effectively is an effort that manifests through empathy, interaction, and response. So that, the speaker and hearer can share, approve and response the message and the utterance.

Using language as a tool of communication has a specific purpose that the hearer can understand our intentions. Therefore, in this case, the response of the hearer is our main concern. (Austin, 1962) argues that by saying or in saying something we are doing something. To get a goal, the speaker tries to transfer the message briefly, clearly and meaningfully to the hearer. Then, the hearer supposed it by giving a response directly. 
Accordingly, the focus of this study is on translation techniques usage and translation acceptability on responding of requesting speech act. Responding to requesting speech act is a response to requesting speech act, it is a part of directive speech act. (Searle, 1979) reveals that the main point of requesting speech act in communication indicates the hearer's response (count as an attempt to get how to do something). Then, the speaker hopes that the hearer can give a response either in the form of verbal or in the form of non-verbal language. Although, the researcher maps out only on the verbal response in this study. (Sarlito, 1995) says that response is the activity or inhibition of the previous activity of an organism resulting from stimulation. (Gulo, 1996) also states that response is the reaction of the receiver after perceiving or understanding the message (depend on stimulation). Then, we can say that response plays an important role in communication. It is essential for the completion of the whole communication system. It enables the sender/speaker to evaluate the effectiveness of the message. It is also inevitably essential in case of two-way communication. Without a response, two-way communications are either ineffective or incomplete.

\section{Review of Previous Study}

Several types of research of translation with the topic of speech act are in the following. (Kuncara, 2012) analyzes the translation of directive speech act in the novel Sang Godfather in the whole types of illocutionary. Then, (Wahyuni, 2014) analyzes the translation of directive speech act in different data source i.e. in the film of Alice in Wonderland/ In her study, she finds the literal translation technique as the dominant technique and the translation quality in the form of accuracy and acceptability tends to be outstanding. (Fitriyana, 2014) analyzes the technique and quality translation of expressive speech act in the novel Stealing Home by Sherryl Woods. The results unveil 19 types of expressive speech act and 11 translation techniques. Whereas, the literal translation technique is similarly as the dominant technique, and shows the impact of applying translation techniques toward the translation quality i.e. by applying literal, amplification addition, pure borrowing, compensation and linguistic compression techniques. The quality of translation accuracy tends to be qualified /accurate. Several studies above are still general and lack of focus because they describe all types of speech act, directive, expressive, and have not exposed the aspect of giving responses from speech acts.

In terms of speech act, there are two studies of translation on this topic. The former, (Valensia, 2014) analyzes the politeness strategy on requesting of speech act in the novel 
Breaking Dawn. The results state that there are four types of politeness strategy i.e. negative politeness, positive politeness, bald on record and on record, finds the friction of politeness strategy in the target text caused by applying amplification addition and reduction techniques. The later, (Mansur, 2014) analyzes the mitigation on commanding of speech act in the two novel series by Harry Potter. The two studies above have focused on a single topic of speech acts, but none has yet exposed the aspect of giving of responses from speech acts. For this reason, the researcher considers this issue as an opportunity to conduct this research focusing on responding of requesting speech act in the novel the Heroes of Olympus Series by Rick Riordan.

\section{The Research Benefits}

This study is expected to provide benefits to the translators in understanding more about the translation process, assessing the acceptability translation, and the translation techniques used in translating the response of requesting speech act especially novel translators that face many genres of the novel. Then, it gives references for translators to pay more attention to the context of situation before translating a text.

\section{Translation Process}

The translation process is a series of activities performed by a translator as the one transfers the message from the source language to the target language (Nababan, 2003). Another meaning is that the process of translation is a series of steps that must be passed by the translator to get to the end result (Machali, 2000). There are three steps of translation process namely, analysis, transfer and restructuring (Nida \& Taber, 1969). This process begins with analyzing the source language into the grammatical and semantic structure of the target language, transferring the meaning and reconstructing the grammatical and semantic structure into the appropriate target text in order to create an equivalent target text.

\section{Translation Techniques}

Translation techniques are defined as procedures to analyze and classify how translation equivalence works. In this study, the researcher uses 18 translation techniques written by (Molina \& Albir, 2002) to analyze the data. The researcher uses this theory because those translation techniques are quite complete and clear to classify each data studied. The 
following are the techniques: (a) Adaptation: this technique is replacing a source text (ST) cultural element with one from the target culture, for example, ST: her skin as white as snow, then in TT: kulitnya seputih kapas. (b) Amplification: this technique introduces details those are not formulated in the ST e.g. information, explicative paraphrasing. Footnotes are a type of amplification. Amplification is in opposition to reduction, for example, Ramadan is coming underway (ST). Bulan puasa kaum muslim segera tiba (TT). (c) Borrowing: this technique takes a word or expression straight from another language. It can be pure (without any change), for example, ST: My mother asks me to take mixer, then in TT: Ibuku memintaku untuk mengambil mixer._Naturalized borrowing (to fit the spelling rules in the TL), for example, ST: My mother asks me to take mixer, then in TT: Ibuku memintaku untuk mengambil mikser. (d) Calque: this technique is literal translation of a foreign word or phrase; it can be lexical or structural, for example, ST: Directorate General, TT: Direktorat Jenderal. (e) Compensation: this technique introduces a ST element of information or stylistic effect in another place in the TT because it cannot be reflected in the same place as in the ST, for example, ST: you can let your imagination go wild with a vision board, TT: melalui papan visi, anda bias membiarkan imajinasi mengembara sejauh mungkin. (f) Description: this technique replaces a term or expression with a description of its form or/and function, for example, ST: she eats panettone, TT: dia makan kue traditional Italia yang dimakan pada saat tahun baru. (g) Discursive creation: this technique establishes a temporary equivalence that is totally unpredictable out of context, for example, ST: she's got a great spike, huh?, TT: dia cantik bukan?. (h) Established equivalent: this technique uses a term or expression recognized (by dictionaries or language in use) as an equivalent in the TL, for example, ST: let's see, TT: mari kita lihat. (i) Generalization: this technique uses a more general or neutral term, for example, ST: I'm going to make a pie, TT: Aku akan membuat kue. (j) Linguistic amplification: this technique adds linguistic elements. This is often used in consecutive interpreting and dubbing, for example, ST: its parents have run off. Give it to me, TT: Orangtuanya telah melarikan diri. Berikan anak itu padaku. (k) Linguistic compression: this technique synthesizes linguistic elements in the TT. This is often used in simultaneous interpreting and in sub-titling, for example, ST: Yes, I can, TT: $Y a$. (l) Literal translation: this technique translates a word or an expression word for word, for example, ST: Killing two birds with one stone, TT: Membunuh dua ekor burung dengan satu batu. (m) Modulation: this technique changes the point of view, focus or cognitive category in relation to the ST; it 
can be lexical or structural, for example, ST: I cut my finger, TT: Jarikuteriris. (n) Particularization: this technique uses a more precise or concrete term. It is in opposition to generalization, for example, ST: I see the air transportation, TT: Aku melihat pesawat. (o) Reduction: this technique suppresses a ST information item in the TT. It is in opposition to amplification, for example, ST: That's kind of perfect, TT: Ini sempurna. (p) Substitution (linguistic, paralinguistic): this technique changes linguistic elements for paralinguistic elements (intonation, gestures). It is used above all in interpreting, for example, ST: (gesture: thanking by putting hand on the chest), TT: Terima kasih. (q) Transposition: this technique changes a grammatical category, for example, ST: My brother works at the Bank, TT: Pekerjaan adikku di Bank. (r) Variation: this technique changes linguistic or paralinguistic elements (intonation, gestures) that affect aspects of linguistic variation: changes of textual tone, style, social dialect, geographical dialect, for example, ST: Let's join us, dude!, TT: Bergabunglah bersama kita, $\underline{\text { mas!. }}$

\section{Translation Acceptability}

Acceptability is the second aspect of assessing the translation quality. In this case, the term acceptability refers to the context of whether a translation has been disclosed in accordance with the rules, norms, and cultures that exist in the target language or not, and that aspect of acceptability must be both macro and micro. If a translation has a high degree of accuracy, it does not necessarily have a high degree of acceptability as well. It means the content or message is not appropriate to the rules, norms, and cultures prevailing within the scope of the target language audience. So that, it will be rejected by the target reader. In short, the aspect of acceptability has important functions and roles in making work of translation to be good quality.

Table1. The Instrument of Acceptability Assessment of Translation

\begin{tabular}{lcl}
\hline $\begin{array}{c}\text { Translation } \\
\text { category }\end{array}$ & Score & \multicolumn{1}{c}{ Qualitative parameters } \\
\hline Acceptable & 3 & $\begin{array}{l}\text { Translation is natural; technical terms used are } \\
\text { commonly used and familiar to the reader; phrases, } \\
\text { clauses, and sentences that are used are in accordance } \\
\text { with the rules of Indonesian. }\end{array}$ \\
Less acceptable & 2 & $\begin{array}{l}\text { In general, translations are already natural; but there is } \\
\text { little problem with the use of technical terms or a few } \\
\text { grammatical errors. }\end{array}$
\end{tabular}




\begin{tabular}{lll}
\hline Unacceptable & Translation is unnatural or feels like a work of \\
& translation; the technical terms used are not commonly \\
& used and are not familiar to the reader; the phrases, \\
& clauses, and sentences used not in accordance with the \\
& Indonesian rules.
\end{tabular}

(Nababan, Nuraeni \& Sumardiono, 2012)

\section{RESEARCH METHOD}

This is a qualitative descriptive research. The data sources are the novels The Heroes of Olympus Series and the minute meeting of FGD (Focus Group Discussion). There are two kinds of data in this research; primary and secondary data.

Primary data in this research are the utterances that contain responding of requesting speech act which is uttered by the characters in the novel The Heroes of Olympus Series in the source text and the translation technique can be found by comparing the findings of data from the source text and target text in order to determine the translation techniques. Then, the translation quality assessed by setting up FGD (focus-group discussion) with two raters to discuss all data that researchers have obtained in determining the quality of the translation (accuracy, acceptability, and readability). Then, the minute meeting of FGD plays as secondary data.

The accumulating of the data is applying a content analysis. The procedure of content analysis are (1) Reading. The researcher reads the novels and its translation, marks the utterances that contain responding of requesting speech act, understands the context of the utterances. (2) Identifying. The researcher identifies the translation techniques used. (3) Calculating. The researcher calculates the frequency of application of translation techniques in translating. (4) Analyzing. The researcher analyzes the impact of translation techniques used toward the translation quality. (5) Reporting. The researcher retells the data which had been analyzed in the form of conclusion (Santosa, 2014).

\section{FINDINGS AND DISCUSSION}

Based on the theory of micro-translation (Molina \& Albir, 2002), the researcher finds some translation techniques in translating The Heroes of Olympus Series into Bahasa. The researcher decides to take the theory of translation techniques by Molina \&Albir because they 
allow us to describe the actual steps taken by the translators in each textual micro-unit and obtain clear data about the general methodological option. Furthermore, the researcher also shows the effect of using translation techniques toward the translation quality in the form of acceptability assessment.

Since this research is a translation research with utterances data, the context must be familiarized. The context of a speech is very influential on the interpretation of speech acts by speakers and hearers. (Sudaryat, 2009) says that context is a feature of nature outside the language that fosters meaning in speech or discourse (the non-linguistic environment of discourse). Kleden in (Sudaryat, 2009) explains that context is the specific space and time facing a person or group of people. Context becomes important when it is experienced in a way that becomes open to readers and interpreted by anyone.

Context is an object or thing that resides with text and becomes the environment or situation of language usage. The context can be a linguistic context and extra-linguistic context (Sudaryanto, 2009). The linguistic context is the context of the elements of language. The linguistic context includes of the preposition, the nature of the verb, the auxiliary verbs, and the positive proposition. The context of extra-linguistics is a context that is not a linguistic element. The extra-linguistic context includes the context of utterances that include prejudice, participants, topics or topic frameworks, settings, channels, and codes (Sudaryanto, 2009).

Therefore, the use of any form and nature of the discourse must pay attention to the context in order to use the language appropriately and to determine the meaning appropriately as well. In other words, language users are always context-bound in using language both linguistic contexts and extra-linguistic contexts because it is very important in understanding the meaning between speakers and hearers.

\section{The Findings of Translation Techniques}

The researcher finds some translation techniques from the results of the translation research of responding of requesting speech act. From analyzing 89 data, the researcher finds 13 translation techniques and 564 times applied at the micro level.

Then, in calculating the frequency of application of translation techniques, the researcher has to compare the findings data in the source text and target text to find the translation techniques used. Furthermore, the sum of frequencies is made up of the average 
that is based on the application of translation techniques. So that, the technique that dominates will be seen. Below is the table of findings of translation techniques and frequency of application in translating the responding of requesting speech act in the novel The Heroes of Olympus Series.

Table 2.The Findings of Micro Translation Techniques

\begin{tabular}{|c|c|c|c|}
\hline No & Translation Techniques & $\Sigma$ & Percentage \\
\hline 1. & Establish equivalent & 339 & $60.10 \%$ \\
\hline 2. & Variation & 97 & $17.19 \%$ \\
\hline \multirow[t]{3}{*}{3.} & Borrowing & & \\
\hline & a. Pure borrowing & 30 & $5.31 \%$ \\
\hline & b. Naturalized borrowing & 2 & $0.35 \%$ \\
\hline 4. & Modulation & 26 & $4.60 \%$ \\
\hline \multirow[t]{4}{*}{5.} & Amplification & & \\
\hline & a. Amplification (Explicit) & 22 & $3.90 \%$ \\
\hline & b. Amplification(Addition) & 9 & $1.59 \%$ \\
\hline & c. Amplification (Paraphrase) & 2 & $0.35 \%$ \\
\hline 6. & Adaptation & 6 & $1.06 \%$ \\
\hline 7. & Discursive creation & 5 & $0.88 \%$ \\
\hline 8. & Transposition & 5 & $0.88 \%$ \\
\hline 9. & Generalization & 4 & $0.70 \%$ \\
\hline 10. & Reduction & 10 & $1.77 \%$ \\
\hline 11. & Literal & 4 & $0.70 \%$ \\
\hline 12. & Substitution & 2 & $0.35 \%$ \\
\hline 13. & Linguistic compression & 1 & $0.17 \%$ \\
\hline & Total & 564 & $100 \%$ \\
\hline
\end{tabular}

\section{The Examples of Findings of Translation Techniques}

1. Establish equivalent: there are 84 data found in this technique and 339 times applied at the micro level, for example: 
ST: "We have to help them,"

"Can you..."

"Let's see."

TT: "Kita harus menolong mereka,"

"Bisakah kau ,

\section{"Mari kita lihat"}

On responding of requesting speech act above, "let's see" is translated into "mari kita lihat". This is appropriate, because the translator translates by using familiar language. So, the message contained in the source text has been well conveyed into the target text.

2. Variation: there are 46 data found in this technique and 97 times applied at the micro level, for example:

ST: "Ma'am,"

"You don't mind helping us one more time, do you?"

\section{"I don't mind,"}

TT: "Bu,"

"Ibu tak keberatan membantu kami sekali lagi, kan?"

"Aku tak keberatan,"

In translating "-n't" which has a negative meaning, the translation can be "tak", "tidak", "bukan" dan "enggak". However, by considering the context in conversation in which an older person responds to someone younger than her, then the translator translates"-n't" in an informal language.

3. Pure borrowing: there are 24 data found in this technique and 30 times applied at the micro level, for example:

ST: "Wish me luck"

"Fight well, Percy Jackson,"

TT: "Doakan semoga aku berhasil."

"Selamat bertarung, Percy Jackson," 
The words "Percy Jackson" is the name of the person. The name is in the source text and translated into the target text with the same word or the name is borrowed without any change at all.

Naturalized borrowing: there are 2 data found in this technique and 2 times applied at the micro level, for example:

ST: "Next time, can I take a polygraph?"

\section{"You're not a typical recruit."}

TT: "Lain kali, boleh aku minta tes pendeteksi kebohongan saja?"

\section{"kau bukanlah recrut biasa."}

4. Modulation: there are 23 data found in this technique and 26 times applied at the micro level, for example:

ST: "would you keep it for me?"

"I'm Pluto's daughter. Everything I touch goes wrong."

TT: "maukah kau menyimpankannya untukku?"

"Aku ini putri Pluto. Aku merusak semua yang kusentuh."

The translation of responding of requesting speech act on the target text is the application of modulation techniques thoroughly by changing the point of view. The word "goes wrong" in the source text is an adjective, and then it is translated into "merusak" in the target text as a verb.

5. Amplification (Explicit): there are 16 data found in this technique and 16 times applied at the micro level, for example:

ST: "Thank you, Gleeson. Take care of him, please."

"I got this McLean,"

TT: "Terima kasih, Gleeson. Tolong jaga ayahku."

“Aku bisa mengatasi ini, McLean,"

The word "got" in the source text is the hidden information. Therefore the word "got" is translated into the target text to "bisa mengatasi" which aims to add the information in order to the target reader can more easily understand. 
Amplification (Addition): there are 16 data found in this technique and 16 times applied at the micro level, for example:

ST: "Okay, give me a safety whistle. They got that in lots of machine shops."

"Coach Hedge would be jealous! Okay, Festus, listen."

TT: "Oke, beri aku peluit bahaya. Yang seperti itu banyak dibengkel mesin."

"Pak pelatih Hedge bakalan iri!Oke Festus, dengarkan."

The addition of word "Pak" to the target text is the wasting-word because by simply translating "coach" to "pelatih" the target reader can already understand its meaning.

Amplification (Paraphrase): there are 2 data found in this technique and 2 times applied at the micro level, for example:

ST: "Could you move?"

"You're ruining the view."

"Right, great view,"

"Happy to move,"

TT: "Bisakah kau bergeser?"

"kau merusak pemandangan."

"Benar, pemandangan yang bagus,"

\section{"aku akan bergeser dengan senang hati."}

6. Adaptation: there are 6 data found in this technique and 6 times applied at the micro level, for example:

ST: "That's great, Leo. Now, can you fix her foot?"

“I'm a mechanic, man. Maybe if she was a car..." He snapped his fingers.

TT: "Hebat Leo. Nah, bisakah kau obati kakinya?"

“Aku ini mekanik, bung. Mungkin kalau Piper mobil..."Leo menjentikkan jari. 
The word "man" in the source text is translated to "bung" in the target text. It shows that the translator translates by adjusting to what is in the culture of the target language.

7. Discursive creation: there are 5 data found in this technique and 5 times applied at the micro level, for example:

ST: “Tell me, why are you worthy of a share in our spoils?'

'What spoils?'

TT: "Beritahu aku kenapa kau layak mendapatkan sebagian dari pampasan kami?"

\section{"Pampasan apa?"}

The words "what spoils?" is translated to "pampasan apa?" becomes slightly ambiguous, because the target reader is not familiar with its translation, but they understand better if "spoils" is translated into "rampasan".

8. Transposition: there are 4 data found in this technique and 5 times applied at the micro level, for example:

ST: "Can you recalibrate the aim - like, towards the other onagers' firing lines?"

“Oh, I like the way you think. They sent me because I excel at messing things up.'

TT: "Bisakah kau mengalibrasi ulang bidikan senjata ini-misalnya kejalur tembakan onager lain?"

\section{“Oh, aku suka cara berpikirmu. Mereka mengutusku karena aku jago mengacau."}

The word "I excel at messing things up" in the source text is a verb phrase. Then, it is translated into "aku jago mengacau" which can be categorized as a noun phrase in the target text. In this case, the transposition technique occurs because of the change of form from the verb phrase to the noun phrase.

9. Generalization: there are 4 data found in this technique and 4 times applied at the micro level, for example: 
ST: Please tell me you have a plan,'.

"This was the players' entrance.

TT: “Tolong katakana padaku kau punya rencana,"

"Ini adalah jalan masuk peserta."

10. Reduction: there are 4 data found in this technique and 4 times applied at the micro level, for example:

ST: "Could we please not talk about him in the past tense?"

'I'm sorry dear. I didn't want to leave your father, of course. It's always so hard, but it was for the best.

TT: “Tolong, bisakah kita tidak memakai kata'dulu' untuk membicarakan ayah?"

'Maafkan aku, sayang. Aku tidak ingin meninggalkan ayahmu, tentu saja. Melakukannya selalu saja berat, tapi itulah yang terbaik.

11. Literal: there are 4 data found in this technique and 4 times applied at the micro level, for example:

ST: “Then help me, or you're all dead!'

"Group hug!"

TT: "Kalau begitu, bantu aku atau kalian semua bakal mati!"

"Pelukan Kelompok!"

12. Substitution: there are 2 data found in this technique and 2 times applied at the micro level, for example:

ST: "Can you get ready?"

"Yeah..."

TT: "Bisakah kau bersiap-siap?"

"Iya..."

13. Linguistic compression: there are 1 data found in this technique and 1 timeapplied at the micro level, for example: 
ST: "Could you and Ella escort the coach back to Camp Half-Blood safely?"

"Yes!"

"We can do that!"

TT: "Bisakah kau dan Ella mengantar pak Pelatih ke Perkemahan Blasteran dengan selamat?"

"Ya!"

“Kami bisa!"

\section{The Findings of Acceptability Translation}

Table 3.The Findings of Acceptability Translation

\begin{tabular}{|c|c|c|c|}
\hline Acceptability Translation & Score & $\Sigma$ & Average \\
\hline a. Acceptable & 3 & 77 & $(3 \times 77)+(2 \times 12)+(1 \times 0)$ \\
\hline b. Less acceptable & 2 & 12 & $\begin{array}{r}89 \\
=231+24\end{array}$ \\
\hline c. Unacceptable & 1 & 0 & 89 \\
\hline & & & $=\underline{255}$ \\
\hline & & & 89 \\
\hline & & & $=2.86$ \\
\hline
\end{tabular}

Of the 89 data obtained from this study, 77 data (86.51\%) were acceptable translations and 12 data (13.48\%) were less acceptable. So, the average of acceptable translations is 2.86 . The value indicates that the translation of responding of requesting speech act in the novel The Heroes of Olympus Series tends to be acceptable. It can be said that with the results of this study, the messages contained in the source text can be well conveyed into the target text. 
Table 4. The Examples of Responding of Requesting Speech Act in the Form of Acceptability Assessment.

\begin{tabular}{|c|c|c|c|}
\hline No & Source Text & Target Text & Acceptability \\
\hline 1 & $\begin{array}{l}\text { Annabeth turned to the guy } \\
\text { with the bow. "Will, would } \\
\text { you take Leo, give him a } \\
\text { tour? Introduce him to his } \\
\text { bunk-mates in Cabin } \\
\text { Nine." } \\
\text { "Sure, Annabeth." }\end{array}$ & $\begin{array}{l}\text { Annabeth } \text { berpaling kepada cowok } \\
\text { pembawa busur. "Will, maukah } \\
\text { kauantar Leo keliling-keliling? } \\
\text { Perkenalkan dia kepada teman-teman } \\
\text { sekamarnya di pondok Sembilan. }\end{array}$ & Acceptable \\
\hline 2 & $\begin{array}{l}\text { "He needs to go straight to } \\
\text { Chiron," Annabeth } \\
\text { decided. } \\
\text { "Drew, would you_", }\end{array}$ & $\begin{array}{l}\text { "Pasti." Drew mengaitkan lengannya } \\
\text { ke lengan Jason. }\end{array}$ & Acceptable \\
\hline 3 & $\begin{array}{l}\text { "We have met," he } \\
\text { decided. "I don't remember } \\
\text { when. Please, if you can } \\
\text { tell me anything_", } \\
\text { "First things first," Reyna } \\
\text { said. "I want to hear your } \\
\text { story." }\end{array}$ & $\begin{array}{l}\text { "kita pernah bertemu." Percy } \\
\text { memutuskan. "Aku tidak ingat kapan. } \\
\text { Tolong,kalau kaubisa memberitahuku- } \\
\text { “ }\end{array}$ & Acceptable \\
\hline 4 & "Next time, can I take a & "Lain kali, boleh aku minta tes & Less \\
\hline
\end{tabular}




\begin{tabular}{|c|c|c|c|}
\hline & polygraph?” & pendeteksi kebohongan saja?" & acceptable \\
\hline & Reyna stood. & Reyna berdiri. & \\
\hline & $\begin{array}{l}\text { "Even if I accept that } \\
\text { you're not an enemy," she } \\
\text { said, "you're not a typical } \\
\text { recruit. The Queen of } \\
\text { Olympus simply doesn't } \\
\text { appear at camp, } \\
\text { announcing a new } \\
\text { demigod." }\end{array}$ & $\begin{array}{l}\text { "Sekalipun aku menerima bahwa } \\
\text { kaubukan musuh," kata Reyna, "kau } \\
\text { bukanlah recrut biasa. Ratu Olympus } \\
\text { tidak pernah muncul begitu saja di } \\
\text { perkemahan, mengumumkan } \\
\text { kedatangan demigod baru." }\end{array}$ & \\
\hline 5 & $\begin{array}{l}\text { "Frank," Percy said, "It's } \\
\text { up to you. Can you help } \\
\text { them?" }\end{array}$ & $\begin{array}{l}\text { "Frank," kata Percy, "semua bergantung } \\
\text { padamu. Bisakah kautolong mereka?" }\end{array}$ & $\begin{array}{l}\text { Less } \\
\text { acceptable }\end{array}$ \\
\hline & $\begin{array}{l}\text { “Oh, gods,"he } \\
\text { murmured."Okay, sure." }\end{array}$ & $\begin{array}{l}\text { "Demi dewa-dewi, "gumam } \\
\text { pemudaitu, "oke, tentusaja" }\end{array}$ & \\
\hline 6 & $\begin{array}{l}\text { "Ma'am" Piper said with } \\
\text { her best smile. "You don't } \\
\text { mind helping us one more } \\
\text { time, do you" }\end{array}$ & $\begin{array}{l}\text { "Bu," kata } \text { Piper sambil } \\
\text { menyunggingkan senyum terbaiknya. } \\
\text { "Ibu takkeberatan membantu kami } \\
\text { sekali lagi, kan?" }\end{array}$ & Acceptable \\
\hline & $\begin{array}{l}\text { "I don't mind," the pilot } \\
\text { agreed }\end{array}$ & "Aku takkeberatan," sang pilot setuju. & \\
\hline
\end{tabular}

From the table, it can be clearly seen that data 1, 2, 3 and 6 show the acceptability of translation. In this study, among the researcher and 2 raters give 3 of the score. It happens because of its data, the translator used 3 translation techniques; establish equivalent, pure borrowing, and variation. By using 3 translation techniques above, the source text can be well conveyed into target text exactly. Then, data 4 and 5 show the less of acceptability of translation which the researcher and 2 raters give 2 of the score on the translation results. In 
this study, the translator used 3 translation techniques, modulation, amplification addition and discursive creation which make the target text less natural by the addition of slightly exaggerated language and the message of the source text translated in opposition to the prevailing culture within the scope of the target reader.

\section{CONCLUSION}

Based on the findings of this study, the researcher finds 13 translation techniques applied in translating the responding of requesting speech act i.e. Establish equivalent, Variation, Borrowing (Pure borrowing and Naturalized borrowing), Modulation, Amplification (Explicit, Addition, and Paraphrase), Adaptation, Discursive creation, Transposition, Generalization, Reduction, Literal, Substitution, and Linguistic compression. Establish equivalent technique is the most dominant technique with the application of 339 times.

Afterward, the translation quality in the form of acceptability assessment in this study tends to be good because the average is 2.86 . Based on an acceptability assessment made by two raters and researcher in a focus group discussion (FGD), there are 77 acceptable data from 89, with the majority of applying Establish equivalent technique. It can be concluded that the use of Establish equivalent that dominates in translating the novel series has a positive impact on the translation quality especially in the form of acceptability assessment.

\section{REFERENCES}

Austin, J. L. (1962). How to Do Thing with Word. New York: Oxford University Press.

Baker, Mona. (1992). In Other Word: A course Book of Translation. London: Routledge.

Brislin, Richard. W (ed). (1976). Translation Applications and Research. New York: Garden Press. Inc.

Catford, J. C. (1965). A Linguistic Theory of Translation. London: Oxford University Press.

Chaer, Abdul. (2004). Linguistik Umum. Jakarta: PT Rineka Cipta. 
Fitriana, Irta. (2014). Analisis Teknik dan Kualitas Terjemahan Tindak Tutur Ekspresif dalam Novel Stealing Home Karya Sherryl Woods. Tesis Surakarta: Universitas Sebelas Maret.

Gulo, W. (1996). Metodologi Penelitian. Jakarta: PT Grasindo.

Keith, Davis. (1993). Human Behavior. Megraw Hill, New York, P. 402-403.

Kuncara, Singgih. D. (2012). Analisis Terjemahan Tindak Tutur Direktif pada Novel Sang Godfather karya Maria Puzo. Tesis Surakarta: Universitas Sebelas Maret.

Larson, Mildred. (1984). Meaning-Based Translation. Newyork: University Press of America Machali, Rochayah. (2000). Pedoman Bagi Penerjemah. Jakarta: Gramedia Widia sarana Indonesia

Mansur, A. A. (2014). Kualitas Terjemahan Bentuk Mitigasi pada Tindak Tutur Memerintah (Commanding) dalam Dua Seri Novel Harry Potter.T esis Surakarta: Universitas Sebelas Maret.

Molina, I., \& Albir, H. (2002). Translation Techniques Revisited: A Dynamic and Fungsionalist Approach. in Meta.: Translation's Journal XLVII, 4.

Nababan, M. R. (2003). Teori Menerjemah Bahasa Inggris. Yogyakarta: Pustaka Pelajar.

Nababan, Nuraeni, \& Sumardiono. (2012). Pengembangan Model Penilaian Kualitas Terjemahan. Sukakarta: UNS.

Newmark, Peter. (1988). A Textbook of Translation. Oxford: Perganon Press.

Nida, E. A. \& Taber, C. R. (1982). The Theory and Practice of Translation. Leiden: E.J. Brill.

Riordan, Rick. (2012). The Heroes of Olympus: The Lost Hero. New York: Disney. Hyperion.

Riordan, Rick. (2013). The Heroes of Olympus: The Son of Neptune. New York: Disney. Hyperion. 
Riordan, Rick. (2014). The Heroes of Olympus: The Mark of Athena. New York: Disney. Hyperion.

Riordan, Rick. (2014). The Heroes of Olympus: The Blood of Olympus. New York: Penguin Group.

Riordan, Rick. (2014). The Heroes of Olympus: The Blood of Olympus. Jakarta: PT Mizan Publika: Reni Indardini.

Riordan, Rick. (2012). The Heroes of Olympus: The Lost Hero. Jakarta: PT Mizan Publika: Reni Indardini.

Riordan, Rick. (2012). The Heroes of Olympus: The Son of Neptune. Jakarta: PT Mizan Publika: Reni Indardini.

Riordan, Rick. (2012). The Heroes of Olympus: The Mark of Athena. Jakarta: PT Mizan Publika: Reni Indardini.

Santosa, Riyadi. (2014). Metode Penelitian Kualitatif. Surakarta: Universitas Sebelas Maret.

Sarwono, Sarlito. (1995). Psikologi Lingkungan. Jakarta: Grasindo.

Searle, John. R. (1979). Expression and Meaning. London: Cambridge University Press.

Sudaryat, Yayat. (2009). Makna Dalam Wacana Prinsip-prinsip Semantik dan Pragmatik. Bandung: CV. Yrama Widya.

Valensia, Ariana. (2014). Analisis Strategi Kesantunan Tindak Tutur Permintaan (Request) dalam Novel Breaking Dawn dan Terjemahnnya awal yang Baru. Tesis Surakarta: Universitas Sebelas Maret.

Wahyuni, Ari. (2014). Analisis Teknik Penerjemahan Tindak Tutur Direktif dalam Film Alice in Wonderland dan Pengaruhnya Terhadap Kualitas Terjemahan. Tesis Surakarta: Universitas Sebelas Maret. 